\title{
Learning of Arabic Language Assignment Models for Early Childhood by Online
}

\author{
Riska Lailatul Andiri, Zahrotun Nikmah, Majidatun Ahmala \\ Received: 09062021 / Accepted: 25062021 / Published online: 30062021 \\ (C) 2021 Association of Indonesian Islamic Kindergarten Teachers Education Study Program
}

\begin{abstract}
Abstrak Pembelajaran yang dilakukan secara dalam jaringan (daring) selama pandemi covid-19 juga dilakukan pada tingkat Pendidikan Anak Usia Dini (PAUD). Memberikan pembelajaran dalam bentuk daring bagi anak usia dini bukanlah hal yang mudah, karena pada usia inilah seorang anak harus belajar banyak hal tentang fisik-motorik, moral, emosi, kognitif, bahasa, cara menyelesaikan masalah, dan lain sebagainya yang akan berpengaruh sepanjang hidupnya, sehingga dikatakan bahwa masa ini dengan masa emas. Pemberian tugas dalam pembelajaran daring ini menjadi salah satu cara yang dilakukan oleh guru dalam memantau perkembangan anak didiknya. Oleh sebab itu, penelitian ini membahas tentang penugasan pada anak usia dini dengan terfokus pada pelajaran bahasa Arab. Penelitian ini menggunakan metode kualitatif dengan menggunakan observasi, wawancara, dan dokumentasi sebagai teknik penelitian. Penelitian ini dilakukan di TK Al-Farobi Surabaya dengan guru TK B sebagai narasumber utama dan wali murid sebagai responden. Hasil dari penelitian ini menunjukkan bahwa terdapat empat penugasan bahasa Arab yang dilakukan guru selama pembelajaran daring, yaitu: 1) model peningkatan kompetensi membaca dan menulis Arab; 2) model menghafal surat pendek; 3) model menghafal asmaul husna dengan gerakan; 3) model menyanyikan kosakata bahasa Arab dengan gerakan.
\end{abstract}

Kata kunci: Anak Usia Dini, bahasa Arab, pembelajaran daring

\begin{abstract}
Learning conducted online during the covid-19 pandemic is also performed at the Early Childhood Education (PAUD) level. Providing online learning for early childhood is not easy because at this age a child should learn many things about physical-motor, moral, emotional, cognitive, language, how to solve problems, and so on that effect throughtout his life, so it is said that this period is the golden age. Giving assignments in online learning is one of the ways that teachers do to monitor the developments of their students. Therefore, this research is about the assignments of early childhood with a focus on Arabic lessons. This research is qualitative methods using observation, interviews, and documentation as research techniques. This research was cinducted at TK-Alfarobi Surabaya with kindergarten B teachers as the main interviews and guardians of students as respondents.. The results of this research show that there are four Arabic assignments performed by the teacher during online learning, there are: 1) a model for increasing competency in Arabic reading and writing; 2) short letter memorization model; 3) the model of memorizing asmaul husna with movements; 4) a model of singing Arabic vocabulary with gestures.
\end{abstract}

Keywords: early childhood education, Arabic Language, Online Learning.

\section{Pendahuluan}

Anak usia dini merupakan kelompok anak yang memiliki pola perkembangan fisik (koordinasi motorik kasar dan halus), kecerdasan (daya pikir, daya cipta), sosio emosional, 
bahasa, dan komunikasi (Mutiah, 2015, p. 7). Oleh sebab itu, baik itu orang tua maupun guru Pendidikan Anak Usia Dini (PAUD) memberikan perhatian yang sangat besar di setiap pengembangannya agar semua unsur yang harus didapatkan anak di usia ini dapat dimiliki dan memberikan pengaruh positif dalam kehidupannya.

Asumsi dasar anak usia 4-6 tahun adalah 1) setiap anak adalah unik; 2) anak berkembang melalui beberapa tahapan; 3) setiap anak adalah pembelajar aktif (Agus F. Tangyong, 2009, p. 2). Setiap guru anak usia dini yang memahami dengan baik hal ini akan mengatur sebuah strategi pembelajaran yang berorientasi pada peningkatan karakteristik dasar anak usia dini sehingga perkembangan anak akan tercapai secara keseluruhan sehingga anak akan siap untuk melanjutkan ke jenjang pendidikan dasar.

Pandemi covid-19 yang terjadi secara tiba-tiba di awal tahun 2020 menyebabkan proses pembelajaran dilaksanakan dalam jarak jauh dengan sistem dalam jaringan (daring). Segenap guru, peserta didik, dan orang tua beradaptasi dengan teknologi yang digunakan sebagai satusatunya media dalam pembelajaran. Suwangsih dkk dalam penelitiannya mengatakan bahwa tantangan yang dihadapi oleh guru pada tingkat PAUD adalah mencari solusi dalam mengimplementasikan pembelajaran jarak jauh dengan sistem daring karena ketiadaan HP android siswa disebabkan keterbatasan ekonomi (Suwangsih et al., 2021, p. 4). Ketiadaan alat komunikasi menjadi kendala yang sangat berat bagi guru maupun orang tua, karena guru akan kesulitan dalam mengatur proses pembelajaran sementara keuangan yang dimiliki orang tua pun diprioritaskan untuk pemenuhan kebutuhan sehari-hari disebabkan terbatasnya gerak orang tua dalam mencari rezeki.

Setelah setahun pembelajaran daring ini dilaksanakan, guru mulai beradaptasi dan menciptakan pembelajaran yang inovatif dan kretaif untuk ketercapaian seluruh kompetensi anak. Orang tua pun bukan hanya mulai menyadari pentingnya alat komunikasi sebagai media penghubung dengan guru dan wali murid yang lainnya, sementara antara guru dan orang tua pun sudah memiliki kesepakatan-kesepakatan yang diterima oleh kedua belah pihak sehingga keterbatasan alat komunikasi karena keterbatasan ekonomi atau yang lainnya dapat di atasi sehingga terjalin kerjasama positif dalam menghadapi pendidikan di saat pandemi covid-19.

Terdapat motivasi khusus bagi orang Islam non Arab ketika belajar bahasa Arab, yaitu mendapatkan tempat yang istimewa di agama dan agar bisa terhubung dengan Al-Qur'an (Thu'aimah, 1989, pp. 31-32). Hubungan erat antara bahasa Arab sebagai bahasa perantara pemahaman akan Islam inilah yang membuat anak-anak sudah belajar keterampilan berbahasa Arab sejak dini melalui belajar Al-Qur'an. Tiga materi yang diajarkan kepada anak dalam mengajarkan Al-Qur'an yang secara tidak langsung belajar bahasa Arab juga yaitu: 1) pengenalan huruf hijaiyah; 2) pengenalan dan pengajaran bahasa Arab; 3) pembacaan AlQur'an dan pengenalan kitab-kitab Allah SWT (Wiyani, 2018, p. 46)

TK Al-Farabi Surabaya, mengkombinasikan pembelajaran bahasa Arab yang berfungsi sebagai bahasa Agama melalui Al-Qur'an maupun asmaul husna dan pembelajaran bahasa Arab yang berfungsi sebagai bahasa komunikasi melalui pemberian kosakata-kosakata sederhana yang dekat anak. Integrasi kedua tujuan dari belajar bahasa Arab tersebut harus diinovasikan oleh guru dalam sebuah pembelajaran daring dengan tetap memperhatikan perkembangan fisik anak usia dini. Oleh sebab itu, sangat menarik sekali untuk mengetahui lebih dalam tentang model-model penugasan yang diberikan oleh guru TK Al-Farabi Surabaya selama pembelajaran daring dalam pelajaran bahasa Arab agar proses pendidikan selama pandemi covid-19 yang sedang dihadapi semua pihak ini tetap berjalan dengan baik dan perkembangan anak dapat berkembang sebagaimana seharusnya.

\section{Metode}

Penelitian ini menggunakan penelitian deskriptif yang akan digunakan untuk menggali data lebih dalam tentang model-model pembelajaran daring pada TK Al-Farabi Surabaya, khususnya pada pelajaran bahasa Arab. Setelah peneliti terjun ke lapangan, yaitu di TK AlFarabi Surabaya, peneliti melihat bahwa pembelajaran daring pada pelajaran bahasa Arab yang sudah sangat aktif terdapat pada anak TK-B, hal ini disebabkan usia anak TK-B adalah usia 
persiapan masuk ke sekolah dasar yang sudah mulai dibekali dengan keterampilan membaca dan menulis, oleh sebab itu kelas ini akan dijadikan oleh peneliti sebagai sampel penelitian.

Proses pengumpulan data dilakukan dengan mengikuti grup WA antara guru dan orang tua, wawancara melalui video call, maupun chatt. Observasi dilakukan oleh peneliti selama proses pemberian tugas kepada peserta didik. Wawancara pada narasumber dilakukan pada wali kelas TK-B yaitu ustadzah Mutmainnah dan wali murid kelas TK-B selaku sampel penelitian untuk mengetahui tentang penugasan-penugasan pada pembelajaran bahasa Arab yang diberikan kepada anak didiknya. Peneliti juga mengumpulkan data-data yang didokumentasikan oleh guru, baik itu berupa data tertulis maupun video-video hasil pengumpulan tugas siswa.

Proses analisis data dilakukan dua kali, yaitu analisis sebelum di lapangan dan analisis selama di lapangan. Sebelum di lapangan, peneliti mengamati sekolah-sekolah anak usia dini yang mengadakan pembelajaran bahasa Arab. Peneliti menemukan bahwa jumlah sekolah anak usia dini yang mengikutsertakan bahasa Arab dalam pembelajarannya tidak terlalu banyak, sebagian besarnya hanya terfokus pada pembacaan huruf hijaiyah untuk mempermudah membaca Al-Qur'an dan menghafal surat pendek. Namun setelah menemukan TK Al-Farabi Surabaya, peneliti melihat ada pembelajaran bahasa Arab dasar melalui pemberian kosakata yang dekat dengan keseharian peserta didik.

Selama di lapangan, peneliti menggunakan analisis model Miles and Huberman yang menggunakan aktivitas berikut: data reduction (reduksi data), data display (penyajian data), conclusion drawing/verification (Sugiyono, 2012, p. 337). Selama proses mereduksi data, peneliti mendapatkan banyak sekali problematika dalam pembelajaran daring, seperti: pembelajaran yang dilakukan di grup whatsapp, media yang digunakan guru selama mengajar, tugas yang diberikan dan pengumpulannya, video call dengan beberapa siswa, pemakaian google form, penggunaan kuota yang semakin banyak, jaringan yang bermasalah selama pembelajaran, permainan dalam pembelajaran secara daring, pendampingan orang tua selama proses belajar.

Setelah menemukan data-data di atas, peneliti menyajikan data dalam bentuk kelompokkelompok permasalahan dalam pembelajaran bahasa Arab daring, yaitu: 1) proses pembelajaran daring bahasa Arab; 2) model-model penugasan dalam pembelajaran daring bahasa Arab; 3) media pembelajaran yang digunakan selama pembelajaran daring bahasa Arab; 4) permainan yang digunakan selama pembelajaran bahasa Arab daring; 5) pendampingan orang tua selama pembelajaran daring.

Berdasarkan data-data yang didapatkan di lapangan, maka peneliti fokus pada satu permasalahan utama, yaitu pada model-model penugasan pembelajaran daring bahasa Arab yang digunakan oleh guru selama pandemi. Peneliti kemudian melanjutkan dengan mencari data-data yang terpusat pada, apa saja model-model penugasan yang digunakan oleh guru selama pembelajaran bahasa Arab, bagaimana implementasinya, dan bagaimana hasil dari penugasan tersebut terhadap perkembangan anak usia dini.

\section{Hasil Penelitian}

Pembelajaran bahasa Arab di TK Al-Farabi Surabaya selama pandemi covid-19 dilakukan secara daring melalui beberapa model penugasan yang dapat berpengaruh terhadap perkembangan fisiknya, seperti: 1) model peningkatan kompetensi membaca dan menulis Arab; 2) model menghafal surat pendek; 3) model menghafal asmaul husna dengan gerakan; 4) model menyanyikan kosakata bahasa Arab dengan gerakan.

Media yang dijadikan jembatan untuk membangun komunikasi dengan wali murid adalah grup Whatsapp, hal ini disebabkan semua wali murid menggunakan aplikasi pesan ini dan jaringannya pun mudah djangkau.

Pengumpulan tugas bervariasi tergantung jenis tugasnya. Apabila tugas berupa video, maka bisa dikumpulkan langsung di grup whatsapp, namun untuk tugas yang tidak bisa dikumpulkan langsung seperti tugas menulis maka sekolah menyediakan waktu khusus, yaitu hari Sabtu dan pengembalian tugas dilakukan setiap hari Senin. Demikian pula apabila ada wali murid yang kesulitan dalam mengumpulkan secara online, maka tugas dapat dikumpulkan di 
hari Sabtu. Kemudahan ini dilakukan agar memudahkan semua pihak dalam pengumpulan tugas, karena tidak semua wali murid mudah untuk beradaptasi dengan menggunakan teknologi secara maksimal.

Evaluasi antara guru dan wali murid pun dilakukan pada hari Sabtu, jadi ketika ada beberapa tugas yang membuat anaknya terlambat untuk mengumpulkan, orang tua berkonsultasi dengan guru untuk mendapatkan masukan dan cara-cara penyelesaiannya agar perkembangan peserta didik pun dapat dikontrol dan dipantau sepenuhhnya oleh guru dan orang tua. Kerjasama antara keduanya dalam menyelesaikan permasalahan peserta didik akan membawa proses pembelajaran daring ini lebih mudah untuk diselesaikan bersama.

\section{Pembahasan}

\section{Model peningkatan kompetensi membaca dan menulis Arab}

Kegiatan membaca yang dilakukan di TK Al-Farobi Surabaya menggunakan buku Batuta, yaitu buku membaca huruf hijaiyah yang diterbtkan sendiri oleh pihak sekolah. Keterampilan menulis yang pertama kali harus dikuasai seorang anak yaitu dengan menulis huruf hijaiyah sebagaimana yang diungkapkan oleh Suhair Muhammad Salama Shash "anak kecil memulai kegiatan menulisnya dengan menggunakan huruf hijaiyah" (Shash, 2006, p. 188).

Untuk dapat membaca, anak usia dini perlu terampil dalam berbagai aspek, yaitu: 1) pendengaran; 2) diskriminasi bentuk dan bunyi; 3) penglihatan; 4) mengingat; 5) koordinasi mata dan tangan (Kurnia, 2019, p. 48). Hasil wawancara pun juga menunjukkan bahwa membaca huruf hijaiyah di TK Al-Farobi Surabaya ini diadakan dengan tujuan agar peserta didik terampil dalam melafazkan huruf hijaiyah dengan benar dan fasih dan mampu membedakan huruf-huruf hijaiyah yang memiliki kemiripan. Muhammad 'Ali Al-Khuli

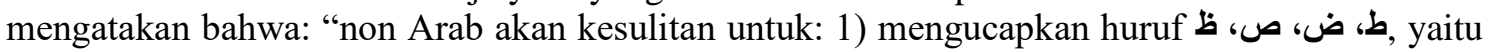
huruf mufakhomah, muthbaqah, dan muhallaqah; 2) mengucapkan huruf $\dot{\tau}$ dan $\dot{\varepsilon}$; 3) membedakan huruf dan huruf hamzah dan $\varepsilon$, huruf dan ق.(Al-Khuli, 1984, p. 47).

Pada keterampilan menulis, TK Al-Farobi Surabaya lebih menekankan pada ketepatan menulis sesuai huruf hijaiyah. Guru memberikan contoh tulisan melalui video untuk kemudian dilihat oleh siswa dan ditirukan cara penulisannya. Dari pemberian tugas seperti ini maka terdapat dua kemampuan yang diperlukan anak untuk menulis, yaitu kemampuan meniru bentuk dan kemampuan menggerakkan alat tulis (Kurnia, 2019, p. 79). Hal ini selaras dengan temuan Dewa Ayu Putri Ariska Pinatih dkk dalam penelitiannya yang mengatakan bahwa dalam menulis terjadi peningkatan motorik halus anak sebesar 85\% (Dewa Ayu Putri Ariska Pinatih1, Rini Kristiantari2, 2015, p. 10).

\section{Model menghafal surat pendek}

R. Fauziyah dkk, dalam penelitiannya mengatakan bahwa ada hubungan yang signifikan antara tsiqoh tahfidz Al-Qur'an dan maharah Al-Lughah Al-'Arabiyah (Fauziah et al., 2020, p. 34). Adanya pengaruh antara menghafal Al-Qur'an dan keterampilan berbahasa (keterampilan mendengar, berbicara, membaca, dan menulis) menunjukkan bahwa bahasa Arab selain berfungsi sebagai bahasa Agama juga berfungsi sebagai bahasa komunikasi sebagaimana bahasa yang lainnya.

TK Al-Farobi Surabaya juga menggunakan tugas ini dengan tujuan: 1) agar peserta didiknya mampu menghafal surat-surat pendek yang ada di Al-Qur'an sejak dini; 2) agar peserta didik mampu membedakan panjang pendeknya suatu bacaan; 3) agar peserta didik dapat melafadzkan bunyi ayat Al-Qur'an tanpa melihat; 4) agar hafalan surat-surat pendek ini juga akan memberikan stimulus positif terhadap perkembangan mereka dalam belajar bahasa Arab.

Konsep pendidikan hafidz Qur'an untuk anak usia dini tidak dapat diterapkan secara instan karena dalam proses haalam pada seorang anak diutuhkan kesabaran dan motivasi kuat dari orang tua (Islamiah et al., 2019, p. 37). Oleh sebab itu, hafalan Al-Qur'an yang diberikan pada TK Al-Farobi Surabaya bukanlah surat-surat yang memiliki ayat yang panjang, tetapi hanya surat-surat pendek yang mudah untuk mereka hafalkan, seperti: surat al-Fatihah, surat al- 
Falaq, surat al-Ikhlas, surat an-Nas, surat al-Lahab, surat al-Kautsar, surat al-Asr. Selain itu, orang tua selaku pembimbing utama dalam proses penghafalan surat pendek mengajarkan hafalan dengan metode pembiasaan, yaitu membiasakan anaknya membaca surat pendek secara rutin dan berulang-ulang sehingga mereka mampu menghafal dengan baik.

\section{Model menghafal asmaul husna dengan gerakan dan bernyanyi}

Dari Abu Hurairah RA, telah bersabda Rasulullah SAW: "Sesungguhnya Allah mempunyai Sembilan puluh sembilan (99) nama, seratus kurang satu, barangsiapa menghitungnya, maka ia akan masuk surga" (HR. Bukari Muslim). Makna "barangsiapa yang menghitungnya, dia akan masuk surga" adalah: 1) bagi yang menghafal dan menguasainya; 2) bagi yang memahami maknanya; 3) bagi yang beribadah kepada Allah SWT dengan melaksanakan konsekuensi dari asmaul husna (Sahla, 2010, pp. 18-19). Dengan adanya pahala surga inilah yang menjadi salah satu motivasi bagi sekolah-sekolah Islam membiasakan peserta didiknya untuk menghafalkan asmaul husna di setiap memulai pelajaran selesai berdo'a.

Pada TK Al-Farobi Surabaya, penghafalan asmaul husna yang dilakukan secara daring divariasi dengan gerakan yang akan semakin membuat peserta didik semakin bersemangat dalam menghafalkan asmaul husna. Adanya gerakan yang mengarah pada kode untuk masingmasing nama Allah akan membuat anak berpartisipasi aktif dalam pembelajaran.

Dalam mengimplementasikan model ini, guru terlebih dahulu membuat sebuah rekaman video yang menunjukkan gerakan asmaul husna beserta lagu dan gerakannya. Dengan membuat sebuah video percontohan maka seorang guru berupaya untuk merancang sebuah media pembelajaran yang memudahkan penyampaian materi pada anak sehingga mudah untuk mereka pahami walaupun tanpa ada tatap muka secara langsung. Sebelum guru membuatkan media video tentang asmaul husna dengan gerakan dan lagu, tentunya guru telah melakkan analisis kebutuhan siswa untuk pembelajaran asmaul husna dengan daring, yang tujuan utamanya adalah memudahkan transfer gerakan dan lagu ke siswa karena ketiadaan tatap muka. Kemudian guru mengkonsep sebuah gerakan dan lagu yang sesuai untuk tiap-tiap nama, yang dilanjutkan dengan proses perekaman video.

Asmaul husna yang diberikan kepada peserta didik tidaklah langsung diberikan semuanya, karena anak usia dini tidak akan mampu menghafalkan semuanya secara langsung tetapi diberikan sedikit demi sedikit sebagaimana dalam video yang diberikan oleh guru secara berkala. Demikian pula dengan orang tua, memberikan hafalan asmaul husna dengan sedikit demi sedikit dan terlebih dahulu mengkondisikan anaknya dalam keadaan senang terlebih dahulu sehingga mudah untuk melakukan penambahan lafal asmaul husna seraya mengulangulang yang telah dihafalkan.

Pembelajaran asmaul husna dengan bernyanyi dan gerakan di TK Al-Farobi Surabaya ini membuat siswa dapat: 1) menambah kepercayaan diri siswa; 2) menambah wawasan tentang nama-nama Allah dalam bahasa Arab; 3) membuat siswa menyesuaikan antara gerakan dan pelafalan yang sesuai. Adanya peran kognitif dan motorik dalam kegiatan ini akan semakin memberikan stimulus terhadap perkembangan anak.

Selain dari ketiga hal di atas, penghafalan asmaul husna yang diikuti dengan gerakangerakan yang menunjukkan makna dari setiap asmaul husna, secara tidak langsung, peserta didik akan belajar kosakata bahasa Arab. Hal ini akan semakin menambah kemampuan peserta didik anak usia dini dalam berbahasa Arab dasar. Dengan melafalkan kosakata bahasa Arab, maka siswa akan melatih keterampilan bicara bahasa Arab.

Dari unsur afektif, pemberian tugas asmaul husna ini mampu menyentuh ranah perasaan siswa lebih dalam lagi ketika orang tua mampu menjelaskan arti dari setiap nama yang dilafalkan dan gerakan yang dipraktekkan, karena setiap lafal asmaul husna memiliki maknamakna positif yang dapat dipraktikkan oleh peserta didik dalam keseharian, seperti sikap saling mengasihi dan menyayangi yang ada dalam ar-Rahman ar-Rahim, maupun yang lainnya. Kedekatan emosional antara orang tua dan anak akan terikat lebih dalam karena komponen afektif dalam sebuah pembelajaran mampu menggambarkan emosi dan perasaan individu sehingga menjadi pengalaman yang bermakna bagi anak (Jamin, 2020, pp. 42-43). 

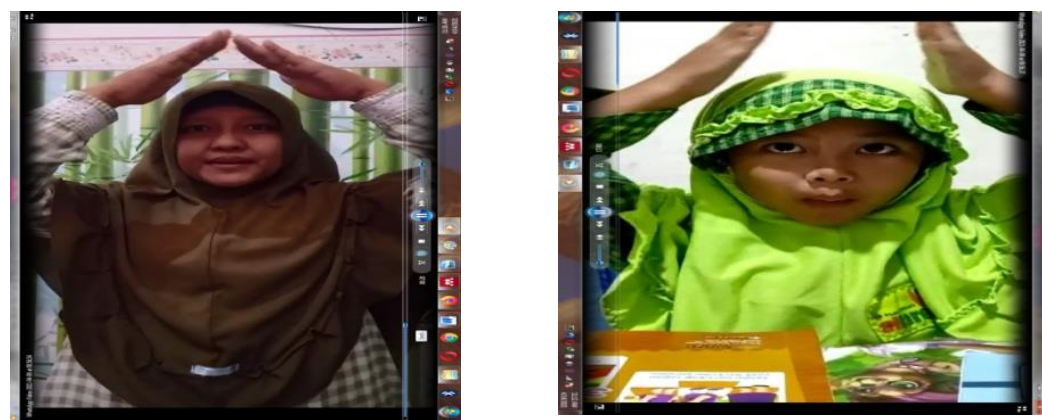

Gambar 1. Bentuk Penugasan Asmaul Husna Guru dan Siswa

Dari tugas ini, nampak sekali bagaimana seorang guru berkreasi dan berinovasi dalam pembelajarannya agar mudah dipahami dan diterima oleh peserta didiknya. Kreativitas guru dalam membuat peserta didiknya memahami akan materi yang diajarkan akan menghasilkan peserta didik yang kreatif, karena kreativitas merupakan salah satu potensi yang dimiliki anak yang perlu dikembangkan dan dipupuk sejak dini (Azis, 2020, p. 81).

Dari tugas-tugas yang dikumpulkan peserta didik, sangat terlihat antusias para peserta didik dalam menyampaikan asmaul husna dengan gerakan. Kerjasama antara orang tua dan anak dalam menyelesaikan tugas ini sangat terlihat dalam setiap videonya, bahkan ketika sang anak lupa beberapa kata namun ingat dengan gerakannya, orang tua berusaha mengingatkan sehingga anaknya mampu mengingatnya kembali dan menyanyikannya dengan baik. Maka, peran orang tua dalam tugas ini sangatlah besar untuk dapat menyelesaikan tugas dengan baik.

Model menyanyikan kosakata bahasa Arab dengan gerakan.

Menghafalkan daftar kosakata yang ada di buku pelajaran memiliki beberapa kekurangan, seperti: 1) menghabiskan waktu yang terlalu banyak; 2) siswa terbebani dengan daftar kosakata yang harus dihafalkan; 3) banyak dari kosakata yang sudah dihafalkan tidak masuk ke memori jangka panjang (long term memory) karena tidak aktif digunakan dalam keseharian dan siswa tidak mampu merecall kembali kosakata yang sudah dipelajari (Ahmala, 2017, p. 167). Apalagi untuk anak usia dini, maka menghafal dengan model konvensional seperti ini akan sangat membebani mereka.

TK Al-Farobi Surabaya, menyatukan hafalan kosakata bahasa Arab dengan gerak dan menanyi yang sangat diminati oleh anak-anak, karena gerak menjadi hal yang sangat kreatif bila dipadukan dengan music yang interpretasikan anak menurut caranya masing-masing. Pengalaman dalam gerak juga mengembangkan daya imajinasinya, karena ia harus menggunakan pancainderanya untuk membentuk suatu gerakan tubuh (Mutiah, 2015, p. 169).

Nyanyian yang baik untuk anak memenuhi kriteria berikut: 1) nyanyian yang dapat membantu pertumbuhan dan perkembangan diri anak (aspek fisik, intelegensi, emosi, dan sosial); 2) nyanyian yang bertolak dari kemampuan yang telah dimiliki anak, yaitu: a) isi lagu sesuai dengan dunia anak; b) bahasa yang digunakan sederhana; c) luas wilayah nada sepadan dengan kesanggupan; c) tema lagu sesuai dengan kurikulum yang digunakan (Akbar, 2020, p. 71). Dari kriteria tersebut TK Al-Farobi Surabaya memberikan nyanyian gubahan dari "lingkaran kecil lingkaran besar" yang sudah sesuai dengan pertumbuhan dan perkembangan anak. Selain itu, tema yang digunakan pun tentang anggota tubuh dalam bahasa Arab yang sudah sesuai dengan kesederhanaan bahasa dan kurikulum yang telah digunakan di TK AlFarobi Surabaya. Jadi, pengambilan nyanyian ini sudah sesuai dengan kriteria nyanyian yang diberikan untuk anak usia dini.

Guru memberikan contoh rekaman video yang dishare di youtube, kemudian peserta didik menirukannya mulai dari lagu gerak dan liriknya. Dalam mentransfer lirik dan lagu yang ada di video, orang tua pun memperagakan di depan anaknya, hal ini akan memperkuat penggunaan keseluruhan indera anak dalam mengamati setiap lirik dan setiap gerakan yang ada pada lagu. Berikut lirik dari lagu yang diberikan oleh guru melalui video: 


\section{عين mata}

أنف hidung

kepala

أذن telinga

.... يـ. ini tanganku

ini kakiku
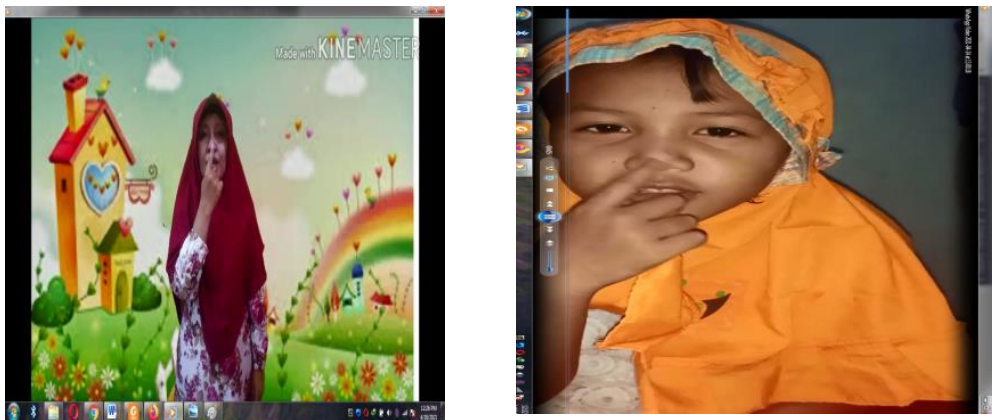

Gambar 2. Bentuk Penugasan Menyanyikan Kosakata dengan Gerakan

Kondisi pembelajaran yang dilakukan dengan pengiriman tugas membuat siswa kehilangan momen rebut dengan teman, tertawa bersama teman, atau pun gangguan-gangguan yang membuat mereka belajar untuk menyelesaikan masalah dalam ertemanan. Namun di sisi lain, kegiatan pembelajaran daring ini memiliki hal-hal positif, seperti: 1) membangun kedekatan antara orang tua dan anak dengan bergerak dan bernyanyi bersama, karena hal ini bisa jadi sangat jarang dilakukan oleh orang tua dan anak, terlebih lagi bagi peserta didik yang kedua orang tuanya bekerja; 2) orang tua akan menjadi lebih kreatif dalam melatih anaknya bernyanyi sesuai dengan video yang diberikan guru; 3) timbulnya semangat berkompetisi antara walimurid dalam memberikan penampilan terbaik untuk putra-putrinya dalam menyelesaikan tugas dari guru; 4) menumbuhkan rasa bangga antara orang tua dan anak ketika telah bersamasama menyelesaikan tugas an mendapatkan apresiasi dari guru.

Orang tua dan guru berperan aktif dalam menyelesaikan setiap tugas yang diberikan oleh guru, karena dalam setiap tugas yang diberikan orang tua juga akan berhadapan dengan perkembangan emosi anak. Peran aktif keduanya dalam mengembangkan emosi anak dilakukan dengan cara peduli dalam mendorong respon positif dan mengajarkan manajemen respon yang tidak sesuai (respon negative) pada anak (Mulyani, 2018, p. 64). Namun, proses membangun emosi anak tersebut sekarang porsinya akan lebih banyak dilakukan oleh orang tua. Maka orang tua akan menjadi pemeran utama dalam mengatasi kesulitan peserta didik dalam mengatur emosi negative anak seperti: marah, sedih, khawatir, dan lain sebagainya selama penyelesaian tugas dari guru.

Penilaian yang dilakukan pada anak usia dini, dilakukan dengan berbagai cara, yaitu: 1) secara langsung melalui pengamatan terus-menerus; 2) secara tidak langsung melalui hasil karya anak baik berupa tulisan, gambar, maupun ungkapan lain yang terkumpul dalam protofolio anak; 3) melihat tingkat pencapaian perkemangan anak dari kemampuan yang sederhana sampai yang kompleks (Agus F. Tangyong, 2009, p. 8). Demikian pula dengan penilaian yang dilakukan di TK-Al-Farobi Surabaya, semua penugasan yang diberikan oleh guru, walaupun dilakukan secara daring, guru juga melakukan penilaian langsung, tidak langsung, dan penilaian pada pencapaian peserta didik. Pada penilaian langsung secara daring ini, guru mengamati tugas-tugas yang sudah dikerjakan peserta didik. Penilaian tidak langsungnya dilihat dari buku prestasi yang merekap kemampuan membaca huruf hijaiyah anak, 
ataupun tugas video yang dikumpulkan. Sedangkan pada pencapaian perkembangan anak, guru melihat perkembangannya secara langsung ketika video call ataupun hasil dari tugas video yang berhubungan dengan gerak, menyanyi, caranya menyelesaikan tugas, yang terkadang terlihat di antara proses pembuatan video.

\section{Simpulan dan Saran}

Pemberian tugas untuk pelajaran bahasa Arab bagi peserta didik tingkat anak usia dini dapat dilakukan dengan memperhatikan perkembangan unsur keterampilan berbahasa, yaitu keterampilan mendengar, keterampilan berbicara, keterampilan membaca, dan keterampilan menulis dan unsur perkembangan peserta didik baik itu secara kognitif maupun secara motorik.

Pada keempat penugasan tersebut, keterampilan mendengar siswa terlihat dari rekaman video yang diberikan oleh guru. Keterampilan berbicara nampak pada penugasan yang berhubungan dengan menyanyikan kosakata baru yang dipraktekkan peserta didik melalui pengiriman video. Keterampilan membaca terlihat dari tugas membaca huruf hijaiyah yang selalu dikontrol oleh orang tua dan guru, sedangkan keterampilan menulis pun nampak pada tugas penulisan huruf hijaiyah yang diberikan contoh oleh gurunya melalui video yang diberikan pada siswa. Pemberian tugas juga tetap memperhatikan perkembangan motorik siswa, hal ini terlihat dari adanya gerakan dan nyanyian yang memang dibutuhkan untuk anak usia dini.

Dalam memberikan stimulus pada siswanya melalui pembelajaran daring, guru tidak hanya berusaha mengkreasi lagu dengan gubahan lirik yang sesuai dengan kurikulum, tetapi guru juga berkreasi dengan membuat video pembelajaran yang bernuansa menarik untuk anakanak sehingga menambah semangat peserta didiknya dalam belajar sambil bernyanyi.

Saran dari penelitian ini adalah dengan diadakannya penugasan yang berhubungan dengan permainan bahasa, karena permainan merupakan aktivitas sehari-hari anak. Guru dapat memberikan tugas pada orang tua dan anak agar saling bermain dengan menggunakan bahasa Arab yang hasilnya dikirimkan ke guru. Tugas ini akan sangat menyenangkan bukan hanya bagi anak tapi juga bagi orang tua karena dapat mempererat kedekatan keduanya.

\section{Daftar Rujukan}

Agus F. Tangyong, D. (2009). Pengembangan Anak Usia Dini: Panduan Bagi Pendidik Anak Usia Dini (N. S. Harsini (ed.)). Gramedia Widiasarana Indonesia.

Ahmala, M. (2017). Ta'lim Al-Mufradhat bi Uslub Al-Muhadtsah Al-Taswiriyah bi Madrasah "Nurul Islam" Al-Ibtidaiyah Al-Islamiyah Sidoarjo. Alfazuna, 01 Nomor 0(2), 163-175. https://doi.org/https://doi.org/10.15642/alfazuna.v1i2.15

Akbar, E. (2020). Metode Belajar Anak Usia Dini. Kencana.

Al-Khuli, M. 'Ali. (1984). Asalib Tadris Al-Lughah Al-'Arabiyah. Al-Mamlakah Al-'Araiyah Al-Su'udiyah.

Azis, D. K. (2020). Pendidikan Kreatif Pada Anak Usia Dini (M. K. Albar (ed.); Edisi digi). Lontar Mediatama.

Dewa Ayu Putri Ariska Pinatih1, Rini Kristiantari2, I. K. A. (2015). Meningkatkan Kemampuan Motorik Halus Dalam Menulis Dengan Metode Pemberian Tugas Berbantuan Media Gambar Pada Anak Kelompok B2 Semester II. E-Journal PG-Paud Universitas Ganesha, 3(1), 1-10.

Fauziah, R., Ritonga, M., \& Alrasi, F. (2020). Korelasi Tsiqah Tahfidz Al-Qur'an Dengan Maharah Al-Lughah Al-'Arabiyyah Mustawa Tsalits Ma'Had Az-Zubair Bin Al-Awwam. El-Tsaqafah: Jurnal Jurusan PBA, 19(1), 25-36. https://doi.org/10.20414/tsaqafah.v19i1.2342

Islamiah, F., Fridani, L., \& Supena, A. (2019). Konsep Pendidikan Hafidz Qur'an pada Anak Usia Dini. Jurnal Obsesi: Jurnal Pendidikan Anak Usia Dini, 3(1), 30. https://doi.org/10.31004/obsesi.v3i1.132

Jamin, N. S. (2020). Pengembangan Afektif Anak Usia Dini (1st ed.). CV jejak.

Kurnia, R. (2019). Bahasa Anak Usia Dini (D. C. dan Y. Solfiah (ed.); 1st ed.). Deepublish.

Mulyani, N. (2018). Perkembangan Dasar Anak Usia Dini: Panduan Mahasiswa, Guru, dan 
Pengelola PAUD (1 (ed.)). Gaya Media.

Mutiah, D. (2015). Psikologi Bermain Anak Usia Dini (3rd ed.). Kencana.

Sahla, A. (2010). Indahnya Asmaul Husna: Rangkaian Nama-Nama Indah Allah SWT untuk Menyejukkan Jiwa. Elex Media Komputindo.

Shash, S. M. S. (2006). 'Ilm Nafs Al-Lughah. Maktabah Zuhara' AlSharq.

Sugiyono. (2012). Metode Penelitian Pendidikan: Pendekatan Kuantitatif, Kualitatif, dan R\&D. Alfabeta.

Suwangsih, A., Rohman, C., \& Farida, I. (2021). Tantangan Pembelajaran Jarak Jauh Masa Pandemi Covid-19 Bagi Guru Raudlatul Athfal. Indonesian Journal of Islamic Early Childhood Education, 5(2), 1-5. https://doi.org/10.51529/ijiece.v5i2.191

Thu'aimah, R. A. (1989). Ta'lim Al-Lughah Al-'Arabiyah li Ghairi Nathiqin biha: Manahijuhu wa Asalibuhu. Al-Mantiqoh Al-Islamiyah Li Tarbiyah wa Al-'Ulum wa Tsaqafah.

Wiyani, N. A. (2018). Manajemen Program Pembiasaan Bagi Anak Usia Dini: Konsep Implementasinya Untuk Membentuk Karakter Anak Usia Dini (I). Gava Media. 